Przegląd Badań Edukacyjnych Educational Studies Review

ISSN 1895-4308

nr 25 (2/2017), s. 307-332

METODY ZBIERANIA

I ANALIZY DANYCH

W BADANIACH EDUKACYJNYCH

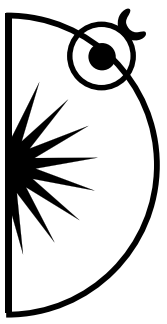

Mirosława Nowak-Dziemianowicz

Uniwersytet Opolski, e-mail: mirka.dziemianowicz@poczta.fm

\title{
Zaangażowane badania jakościowe - perspektywa autobiograficzna
}

DOI: http://dx.doi.org/10.12775/PBE.2014.032

\section{Engaged Qualitative Research - an Autobiographical Perspective}

\begin{abstract}
:
The presented article is an attempt to reconstruct/retrospect my professional biography in its methodological section. It is a description of the way I went to become a biographic, narrative scholar. It is also a description of the reasons - theories, concepts, discussions and disputes that accompanied me on the way. I present my critical attitude towards Polish school and Polish education, posing questions about education, school and teacher.

The second matter that organizes my research is the question about interpersonal relationships, intimacy, marriage, family and what is happening between: spouses, partners, parents and children. I ask what in our relationships with others favours a happy, good life and what hinders it, limits it and becomes a development obstacle.
\end{abstract}

Key words: qualitative research, scientific biography, education, school, marriage.

\section{Wprowadzenie}

Przełom postmodernistyczny oraz towarzyszący mu upadek „Wielkich Narracji” w mojej biografii traktuję jako ponowne narodziny lub moment własnej emancypacji. Czekałam na ten moment wiele jałowych lat w Akademii, próbując z lepszym lub gorszym skutkiem wypełniać założenia i wymagania pozytywistycznego paradygmatu badań. Czyniąc to, wiedziałam jednak, iż nie jestem 
u siebie, że poruszam się w obcej, narzuconej mi i sztucznej dla mnie perspektywie badawczej. Postmodernizm z jego zakwestionowaniem dogmatycznych twierdzeń o identyczności badań społecznych i przyrodniczych, wymogu ich obiektywizacji i generalizacji, otworzył nauki społeczne zarówno na inne, niż znane i obecne dotąd w naukach przyrodniczych sposoby poznawania rzeczywistości, jak i poddał w wątpliwość czy też pozwolił na namysł nad funkcjonowaniem świata nauki, znaczenia prawdy, możliwości i granic ludzkiego poznania. Rozwijane przeze mnie badania jakościowe stały się możliwe właśnie dzięki impulsowi postmodernistycznemu, dzięki odzyskanej zdolności do zakwestionowania tego, co traktowaliśmy jako aksjomat lub nawet jako dogmat, podważeniu zasadności tego, co świadczyło o naukowości i odróżniało go od wszystkiego, co naukowe nie jest. I bez względu na bogatą i bardzo inspirującą dyskusję wokół postmodernizmu, jaka przetoczyła się w ciągu ostatnich kilkudziesięciu lat, bez względu na to, czy zgadzam się czy nie z głównymi tezami (zarzutami) pod adresem tego prądu intelektualnego, jestem przekonana, iż otworzył on drogę, możliwość i prawo do odmiennego, niż pozytywistyczne myślenia o świecie społecznym we wspólnocie uczonych.

Prezentowany artykuł będzie rekonstrukcją/retrospekcją mojej zawodowej biografii w jej fragmencie metodologicznym. Stanowi opis drogi jaką przebyłam, stając się badaczką narracyjną, biograficzną. Będzie także opisem towarzyszących mi w tej drodze uzasadnień - teorii, koncepcji, dyskusji i sporów.

\section{Narodziny Badaczki - namysł nad nauczycielem, szkołą i edukacją.}

Moje pierwsze zaangażowania badawcze związane były z Zespołem Wrocławskiej Szkoły Przyszłości. Współpracowałam w nim między innymi z prof. zw. dr hab. Ryszardem Łukaszewiczem, prof. zw. dr hab. Wiesławem Łukaszewskim, prof. zw. dr hab. Janem Waszkiewiczem, dr hab. Jolantą Zwiernik. Zadanie jakie otrzymałam polegało na prowadzeniu badań nad teoretycznymi uzasadnieniami oraz praktycznymi zastosowaniami metod, form oraz realizacji procesu kształcenia nauczycieli oraz opracowanie nowatorskiego, eksperymentalnego modelu przygotowania nauczycieli do pracy w „szkole przyszłości”, będącej autorskim projektem tego Zespołu. Przygotowałam wówczas projekt eksperymentu pedagogicznego, dotyczący autonomii osobowości nauczyciela i jej znaczenia dla realizacji prorozwojowej, umożliwiającej samorealizację i autonomię ucznia edukacji. W taki sposób zagadnienia związane ze społeczną rolą nauczyciela, jego osobowością, możliwościami i ograniczeniami w procesie rozwoju ucznia wpisały się na stałe w nurt moich naukowych poszukiwań. 
Mój pierwszy projekt badawczy dotyczył autonomii osobowości nauczyciela. Punktem wyjścia do planowanych wówczas badań stała się teza, zgodnie z którą tylko autonomiczny nauczyciel może pozwolić na rozwój uczniów w kierunku niezależności, tylko taki nauczyciel stwarza uczniom warunki do samorozwoju, dając im szansę na emancypację. W celu potwierdzenia przyjętej przez siebie tezy zaplanowałam eksperyment pedagogiczny. Zaplanowałam w oparciu o diagnostyczne narzędzia psychologiczne wybór dwu grup nauczycieli: autonomicznych oraz nieautonomicznych. Następnie chciałam dokonać pomiaru cech występujących u dzieci, wskazujących na ich poziom autonomii przed eksperymentem. Następnie pragnęłam zaproponować roczną pracę nauczycieli z grupy autonomicznej i nieautonomicznej z dziećmi tymi samymi metodami, według tego samego programu. Po upłynięciu jednego roku chciałam powtórzyć diagnozę sprawdzającą u dzieci ich poziom autonomii. Przyjęłam, że w grupie dzieci pracującej z nauczycielami autonomicznymi poziom autonomii wzrośnie a u dzieci pracujących z nauczycielami nieautonomicznymi pozostanie taki sam lub nawet będzie mniejszy. W taki oto sposób, na podstawie pedagogicznych badań eksperymentalnych, chciałam potwierdzić tezę, iż tylko autonomiczny nauczyciel pozwala na rozwój ucznia w kierunku autonomii.

Przystępując do badań, zgodnie z procedurą postępowania badawczego, mieszczącego się w orientacji pozytywistycznej, dokonałam operacjonalizacji pojęcia autonomia osobowości. Przyjęłam za Obuchowskim (1985), iż „autonomia jednostki jest rodzajem niezależności osoby od zdarzeń, w których ona biernie lub czynnie uczestniczy". Obuchowski stwierdza, że z pełną realizacją możliwości człowieka mamy do czynienia wówczas, gdy niektóre jego zachowania prowadzą do zmian. Zmiany te związane są zaś z realizację celu wytworzonego przez jednostkę do realizacji jej dążeń nadrzędnych w stosunku do tego celu. Te zamierzone, wytwarzane przez jednostkę cele przeciwstawia Obuchowski celom narzuconym, będącym imitacją, odwzorowaniem czy naśladownictwem celów innych ludzi, celów uznawanych za pożądane czy wartościowe. „O pełnej autonomii człowieka można mówić wówczas, gdy cele przez niego wytworzone zakładają wykorzystanie jego możliwości i ich rozwój." (por. Studia z psychologii emocji, motywacji i osobowości, 1985, s. 77-78).

Tak zoperacjonalizowaną zmienną przekształciłam w następnym etapie badań na wskaźniki. Oparłam je na koncepcjach psychologicznych, które wskazują na właściwości rozwoju osobowości zbliżające człowieka do autonomii. Są to:

- poczucie wpływu na zdarzenia polegające na postrzeganiu siebie jako sprawcy, przyczyny własnego losu, 
- wewnętrzne umiejscowienie kontroli wzmocnień,

- twórczość, innowacyjność,

- wewnątrzsterowność: podejmowanie działań dla satysfakcji wynikającej z samej aktywności, kierowanie się motywem kompetencji, a nie zakazem czy nakazem.

W celu wyodrębnienia dwóch grup nauczycieli - autonomicznych i nieautonomicznych zastosowałam narzędzia psychologiczne. Były to standardowe testy, takie jak:

Skala I-E - opracowana przez J. Rottera z Ohio State University. Jest ona przeznaczona do pomiaru zgeneralizowanych oczekiwań jednostki, co do istnienia związku między jej własnymi zachowaniami a wzmocnieniami jakie otrzymuje. Według poglądów autora istnieje przedział, na którego jednym krańcu znajdują się osoby przekonane, że otrzymywane przez nie wzmocnienia są niezależne od podejmowanych przez nie działań (poczucie zewnętrznego umiejscowienia kontroli), na drugim natomiast krańcu - osoby, które żywią przekonanie, że wzmocnienia te zależy ud ich własnych poczynań (poczucie wewnętrznego umiejscowienia kontroli). Skala I-E służy do pomiaru położenia danej osoby w tym właśnie przedziale.

Technika AZE, opracowana przez W. Lukaszewskiego. Jest to technika przygotowana do badań nad nauczycielami i z nimi właśnie wykonano badania sondażowe. Przeznaczona jest ona do badań nad ustosunkowaniem do zmian zachodzących w sobie samym. Pozwala ustalić pozytywny stosunek do zmian i tendencje do ich poszukiwania (wzmagania zmian) lub negatywny stosunek do zmian i tendencje do ich unikania. Można zatem powiedzieć, że AZE mierzy tendencję do postawy konserwatywnej lub innowacyjnej w odniesieniu do stanów własnej osoby.

Technika mierząca tendencję do ograniczania stymulacji innych (OST), również opracowana przez W. Łukaszewskiego (1978). Jest ona przeznaczona do badania tendencji do wspomagania lub ograniczania możliwości zmian zachodzących w innych ludziach. Ogólniej można powiedzieć, że technika ta mierzy tendencję do postawy konserwatywnej lub innowacyjnej w stosunku do innego człowieka. Stosując tę technikę przyjęłam założenie, iż osobowość człowieka może rozwijać się w kierunku autonomii tylko wówczas, gdy człowiek ten ma zgeneralizowaną tendencję do wspomagania zmian zachodzących w innych ludziach, czyli ma do nich pozytywny stosunek. Człowiek autonomiczny nie ogranicza możliwości zmian innych. Jego pozytywny stosunek do zmiany zarówno w sobie, jak i innych, pozwala na autonomię. 
Kwestionariusz aprobaty społecznej (KAS). Opracowany przez J. Wilczyńską i R. Drwala (1980) kwestionariusz aprobaty społecznej (KAS) mierzy zapotrzebowanie osób badanych na aprobatę społeczną. Osoby takie traktuje się jako nieautonomiczne, zależne od innych, dążące do aprobaty, akceptacji i społecznego wsparcia.

Technika opracowana przez P. Pacewicza, nazywana AKS. Składa się ona z dwu części. Pierwsza służy do pomiaru oceny typowej szkoły i typowego nauczyciela, druga - do pomiaru idealnego nauczyciela i idealnej szkoły. Obie łącznie służą do pomiaru akceptacji systemu szkolnego. Jest to technika wywiadu. W pytaniach wywiadu skoncentrowałam się na uzyskaniu od badanych ocen typowej szkoły i typowego nauczyciela oraz szkoły idealnej i idealnego nauczyciela. Interesował mnie również poziom zgodności między opisem stanu idealnego (idealna szkoła i nauczyciel) a typowego.

Uzyskane wówczas wyniki pokazały, iż większość badanych nauczycieli to osoby o zewnętrznym umiejscowieniu kontroli wzmocnień. Oznacza to, że nie widzą oni związku między własnymi działaniami a ich skutkami, że swoje życie spostrzegają w kategoriach losu, przypadku. Okazało się także, że większość nauczycieli wyraża negatywny stosunek do zmian i brak tendencji do ich poszukiwania. Dominującą wśród badanych nauczycieli postawą jest postawa konserwatywna, polegająca na ograniczaniu zmian zachodzących u innych ludzi oraz duże zapotrzebowanie na aprobatę społeczną.

Tak interpretowałam je w jednym ze swoich tekstów:

„Refleksje pojawiające się po wywiadach z nauczycielami można zamknąć w kilku uwagach. Nauczyciele krytykują typową szkołę i panującą w niej atmosferę, którą postrzegają jako pełną napięcia i lęku dla nich samych. Źródłem owych napięć i lęków są w percepcji nauczycieli dyrektorzy szkół, wizytatorzy oraz pozostałe władze oświatowe. Zdaniem nauczycieli owe napięcia i lęki nie są postrzegane przez uczniów, dla których typowa szkoła jest miejscem przyjemnym, bez zagrożeń. Szkoły idealnej, jej atmosfery, generalnie nie potrafią sobie wyobrazić, podają stwierdzenia typu: Przecież musi być dyrektor i dyscyplina, ktoś tym musi kierować, a to zawsze wiąze się z lękiem i poczuciem podporzadkowania.

Mówiąc o poczuciu własnej niezależności nauczyciele twierdzili, że jest to we współczesnej szkole niemożliwe do osiągnięcia. Uważali, że za dużo jest osób, od których są zależni. Padały stwierdzenia typu „ode mnie i tak nic nie zależy”. Zupełnie inaczej postrzegana była niezależność uczniów. Twierdzono, że uczniowie zachowują się tak, ,jakby im wszystko było wolno". Większość nauczycieli 
wyobraża sobie idealną szkołę jako tę, w której będą mogli się czuć niezależni. Nie potrafią jednak tej wizji skonkretyzować.

$\mathrm{Z}$ badań tych wyłania się obraz nauczyciela niezadowolonego z pełnionej przez siebie funkcji zawodowej, sfrustrowanego sytuacją panującą w szkole, biernego i niezdolnego do zmiany. Nauczyciela, który nie znajduje żadnej strategii rozwiązania niekorzystnej sytuacji, w jakiej się znalazł. Poczucie niezadowolenia nie jest jednak dla niego motorem zmiany, punktem wyjścia do twórczych poszukiwań, w wyniku których zarówno szkoła, jak i on sam staliby się inni." (Nowak-Dziemianowicz, 2014, s. 136)

Z powyższej prezentacji wynika wyraźnie, iż mój projekt badwczy zakończył się w fazie pierwszej, tej, która miała służyć wyodrębnieniu dwóch grup nauczycieli: eksperymentalnej, złożonej z autonomicznych nauczycieli oraz kontrolnej, w skład której weszliby nauczyciele nieautonomiczni. Okazało się jednak, że tak przeprowadzone badania prowadzą do wniosku, iż w Polsce w latach 90. nie było autonomicznych nauczycieli. Czy uzyskany wynik był adekwatny do rzeczywistości polskiej szkoły? Czy wybierając jako metodę badawczą eksperyment pedagogiczny, którego warunkiem było znalezienie i wyodrębnienie dwóch grup nauczycieli nie popełniłam błędu uprzednich nastawień, błędu opartego na przedrozumieniu? Czy tzw. „operacjonalizacja zmiennej" czyli decyzja dotycząca tego, jakie cechy osobowości pozwalają o jednych ludziach powiedzieć, że są autonomiczni a innym takiej właściwości odmówić nie była wówczas błędem młodej badaczki? Na pewno przyjęcie jakichś teoretycznych założeń wstępnych co do istoty badanej cechy (w moim przypadku była to autonomia osobowości) przesądziło zarówno o przebiegu, jak i o wyniku całego badania.

Ten wynik jednakże nie zniechęcił mnie . Nadal prowadziłam badania w zakresie problematyki diagnozowania funkcjonowania szkoły, jej społeczno-kulturowego (także ideologicznego) kontekstu. Pozwoliły mi one na rozwój wyobraźni oraz kreatywnej postawy wobec rzeczywistości edukacyjnej. Te pierwsze nieudane badania zainicjowały krytyczne myślenie o szkole, innowacyjne podejście do edukacji. Inspiracje takiego myślenia stanowiły wówczas prace Ilicha „Społeczeństwo bez szkoły”, Łukaszewskiego „Szanse rozwoju osobowości” czy też Brunera „Poza dostarczone informacje”. W tym czasie pojawiło i ugruntowało się moje przekonanie o tym, że możliwy jest model szkoły odmienny od powszechnej, behawioralnej i zewnątrzsterownej. Szkoła, która jest szansą na rozwój, na emancypację wszystkich obecnych w niej ludzi: zarówno nauczycieli, jak i uczniów. Całą moją opartą na doświadczeniu kry- 
tyczną postawę wobec polskiej szkoły i polskiej edukacji inspirowało pytanie o edukację, szkołę, nauczyciela.

Metodologiczna orientacja tych badań ewoluowała i była już inna. Zwróciłam się w stronę krytycznych analiz oraz opisów i diagnoz opartych na lekturach, obserwacjach, działaniach praktycznych, zawsze jednak uzupełnionych o szeroki kontekst społeczno-kulturowy, zawsze nieoczywistych, będących w sporach i spory wywołujących.

Szczególnie angażowało mnie przeświadczenie, iż polska szkoła, behawioralna, oparta na zewnątrzsterownym systemie wzmocnień (kar i nagród, które jak wiadomo oparte na tym samym mechanizmie różnią się wyłącznie znakiem) nie pobudza do myślenia, nie rozwija wyobraźni i kreatywności, nie odwołuje się do motywacji wewnętrznej. Ponadto nie stwarza warunków do działań opartych na motywie kompetencji, autotelicznie rozumianej doskonałości czy choćby dążeniu do samodoskonalenia lub samorealizacji. Jest instytucją opresyjną, nastawioną na posłuszeństwo i dyscyplinę, które zamieniła ze środka (co także budziłoby mój opór) na swój najważniejszy, stale na nowo definiowany cel. Posłuszeństwo i dyscyplina, nie mające nic wspólnego ze „skutecznym zdziwieniem”, które tak cenił J. Bruner sprawiły, iż to swoje pierwsze naukowe zadanie, mój pierwszy tekst potraktowałam jak odpowiedź na własne problemy; odpowiedź na pytania, jakie stawiałam sobie zmuszając się do posłuszeństwa $\mathrm{w}$ dobrym wrocławskim liceum, w który przyszło mi w latach 70-tych pełnić rolę uczennicy. Świadomie i celowo odwołuję się już przy opisie moich pierwszych naukowych działań do subiektywnych doświadczeń. Humanistyka i nauki społeczne są dla mnie (i zawsze były) okazją do szukania odpowiedzi przede wszystkim na własne - ważne dla mnie pytania. Według mnie istotą humanistyki i nauk społecznych jest właśnie ich także subiektywny charakter, ich związek z doświadczeniem każdego z nas. Badacza i osoby badanej, słuchającego i rozmówcy, uczonego i tego, którego uczony opisuje i bada. Zajmujemy się problemami ważnymi także dla nas samych, odwołujemy się, często nieświadomie, do własnych doświadczeń, przeżyć, opresji czy blokad. A skoro jesteśmy częścią wspólnoty, skoro nasze doświadczenie ma zawsze społeczny charakter, odwołujemy się w tych opisach oraz w uzasadniających je badaniach do doświadczeń innych ludzi, do doświadczeń wspólnoty. Humanistyka i nauki społeczne są zawsze zakorzenione jednocześnie w naszym wspólnym i jednostkowym doświadczeniu. Rekonstrukcja tego doświadczenia, jego opis, próba zrozumienia stały się dla mnie zadaniem podstawowym. $\mathrm{Z}$ tego właśnie powodu zajęłam się krytycznymi badaniami szkoły i edukacji. Ten osobisty, subiektywny i zaangażowany wymiar badań tak zasygnalizo- 
wałam we wstępie do wydanej w 2001 roku książki pt. „Oblicza nauczyciela. Oblicza szkoły":

„Celem wysiłku badawczego, którego rezultatem są zamieszczone w niniejszym zbiorze teksty było, jak sądzę dzisiaj z perspektywy czasu, moje pragnienie zredukowania niewiedzy, rozwianie wątpliwości oraz pozbycie się napięcia, które towarzyszy mi zawsze wtedy, kiedy wchodzę w kontakt ze szkołą jako instytucją i nauczycielem jako rolą. Moja niewiedza związana była z pytaniem: Jaki jest współczesny, polski nauczyciel, co daje mu prawo do kierowania innymi, wywierania wpływu, decydowania o egzystencjalnych wyborach i decyzjach młodych ludzi? Moje wątpliwości wiązały się z pytaniem o to, czy relacja nauczyciel - uczeń musi być zawsze sprowadzona na poziom formalny, czy musi być spotkaniem z rolą a nie z człowiekiem? Moje napięcie związane jest jak sądzę z przymusem i opresją jakich doświadczyłam podczas własnej edukacji, jednakże dzisiaj, także dzięki doświadczeniu poznawczemu i badawczemu zdobytemu podczas gromadzenia informacji związanych z poszukiwaniem odpowiedzi na moje pytania dotyczące zawodu nauczyciela wiem, iż przymus ten i opresja, charakterystyczne dla szkół polskich lat 70-tych stały się jednym z czynników umożliwiających mi opór i niezgodę na zastaną rzeczywistość, stały się moją własną szansą na emancypację. Dziękuję Wam za to moi nauczyciele.” (Nowak-Dziemianowicz, 2001 s. 5).

Szukając odpowiedzi na pytanie o możliwości zmiany edukacji, szkoły i nauczyciela moją uwagę zwróciłam ku edukacji alternatywnej, próbowałam opisać założenia, na jakich koncepcje te się opierają żeby następnie przejść do problematyki związanej z rolą nauczyciela, z jego osobowością i związanymi $\mathrm{z}$ tym pytaniami. W tym obszarze moich badań kształtowała i umacniała się moja postawa krytyczna wobec polskiej szkoły i polskiego nauczyciela. Próbowałam demaskować wszelkie przejawy pozoru, „gier” jakie w swej zawodowej codzienności stosują polscy nauczyciele. Próbowałam odpowiedzieć na pytanie: jaki jest współczesny, polski nauczyciel, stawiając się w ten sposób niejako w opozycji wobec bardziej powszechnego w polskiej pedagogice pytania, które dotyczy raczej tego jaki powinien być polski nauczyciel. To rozróżnienie na normatywne, modelowe czy nawet życzeniowe podejście do społecznej roli nauczyciela, do jego profesjonalizmu przeciwstawione podejściu diagnostycznemu, opisowemu, pozbawionemu w punkcie wyjścia ukrytych przedzałożeń, opartych na różnych idealizacjach związanych z rolą nauczyciela, uważam za to, co wyróżnia i co odróżnia moje teksty pedeutologiczne od wielu innych, publikowanych w tym czasie. Ważnym projektem badawczym związanym z tą 
problematyką był wówczas projekt, który realizowałam wspólnie ze studentami pedagogiki Uniwersytetu Wrocławskiego, skupionymi w kole naukowym o nazwie „W poszukiwaniu nowej pedagogiki”, przeze mnie kierowanym. Naszym zamierzeniem badawczym było wówczas przejście od krytycznej refleksji nad polską edukacją oraz jej podstawową instytucją, jaką jest szkoła, do działania zorientowanego na zmianę. Dlatego w roku 1993 podjęłam pracę nauczycielki edukacji wczesnoszkolnej w szkole podstawowej nr 63 we Wrocławiu. Pracując w szkole (równolegle do pracy na Uniwersytecie Wrocławskim) prowadziłam badania, które wówczas, w oparciu o dostępną literaturę metodologiczną nazywaliśmy obserwacją uczestniczącą, dzisiaj zaliczyłabym je do badań w działaniu. Razem ze studentami z naukowego koła pedagogiki chcieliśmy zarówno weryfikować naszą teoretyczną wiedzę na temat edukacji i szkoły, chcieliśmy poznać „od środka” tę instytucję edukacyjną oraz bardzo pragnęliśmy wprowadzić w niej zmiany. Kategoria zmiany społecznej w Polsce na początku lat dziewięćdziesiątych byłą niezwykle nośna i inspirująca. Zmiana polityczna, która się wówczas dokonała budziła nadzieję także na dalsze, społeczne transformacje. Jako pedagodzy czuliśmy się wówczas odpowiedzialni za zmiany w obszarze edukacji i nieco naiwnie wierzyliśmy, że można ewolucyjnie, od środka zmienić polską szkołę. To trwające pięć lat doświadczenie zakończyło się opublikowaniem przeze mnie książki (Nowak-Dziemianowicz, 2014), w której krytycznie zinterpretowałam zarówno zebrane podczas tego działania doświadczenia, jak i wiele zaobserwowanych w tej szkole pedagogicznych praktyk. W następnym okresie mojej pracy badawczej wróciłam do tego doświadczenia oraz do tych badań. Z perspektywy lat oraz w optyce, jaką otworzyły przede mną badania w działaniu mogłam dostrzec nie tylko opresyjny wymiar badanej przeze mnie i moich studentów szkoły, nie tylko krytycznie opisać zachodzące w niej procesy i relacje. Miałam również sposobność poddać krytycznej refleksji nasze własne działania oraz stojące za nimi zaangażowanie. Ten przykład, obie publikacje dotyczące tych samych doświadczeń, oparte na tych samych badaniach pokazują swoistą zmianę mojej orientacji badawczej: od krytyki edukacji, szkoły i nauczyciela przeszłam do próby rozumienia tego, co dzieje się w tej instytucji, co dzieje się z pracującymi w niej ludźmi i dlaczego tak się dzieje.

Myślę, iż ta moja droga od eksperymentu pedagogicznego, ulokowanego w paradygmacie pozytywistycznym, zakończonego opublikowaną diagnozą osobowości nauczyciela $\mathrm{w}$ aspekcie jego autonomii poprzez badania uczestniczące aż do krytycznej analizy dyskursu władzy i władzy nad dyskursem (zaprezentowanej w tekście "Pedagogika dyskursywna - nadzieje i możliwości" 
[Nowak-Dziemianowicz, 2011]) pokazuje, w jaki sposób zmierzałam (dzisiaj wydaje się, iż bardzo konsekwentnie) w stronę zaangażowanych badań jakościowych. Jedno $z$ tych zaangażowań zaktywizowało niemal całe środowisko pedagogiczne. Był nim projekt nowego modelu kształcenia nauczycieli. Zaangażowanie się w ten problem podyktowane było dwoma względami. Po pierwsze jest to zagadnienie należące do sfery publicznej i dotyczy bardzo różnych instytucji społecznych oraz podmiotów sprawujących realną władzę. Po drugie jako członek Rady Głównej Szkolnictwa Wyższego w latach 2006 - 2009 otrzymałam zadanie przygotowania wraz z zespołem pedagogów standardu kształcenia nauczycieli. Polskie środowisko pedagogiczne zaproponowało wówczas oparty o autorską, wypracowaną w zespole koncepcję ich kształcenia kadr nauczycielskich (Nowak-Dziemianowicz, 2011).

\section{Propozycja nowego modelu kształcenia nauczycieli}

Wszelkie refleksje dotyczące stworzenia nowego projektu kształcenia nauczycieli uczyniły punktem wyjścia krytykę współczesnej szkoły oraz obecnego w niej nauczyciela.

Wyniki badań pedagogicznych, socjologicznych i psychologicznych w tym zakresie pokazują niezmiennie asymetryczność kompetencji zawodowych współczesnych polskich nauczycieli. Są oni jako grupa zawodowa dobrze przygotowani merytorycznie (w zakresie wiedzy nauczanego przedmiotu) oraz dydaktycznie (w zakresie wiedzy metodyki i dydaktyk szczegółowych). Niewystarczające jest natomiast pedagogiczno-psychologiczne przygotowanie nauczycieli (Kwiatkowska, 2007).

Podstawowe argumenty, uzasadniające potrzebę przygotowania odmiennej od dotychczasowej koncepcji, struktury i organizacji kształcenia nauczycieli to:

- Zapisy zawarte w obowiązujących rozporządzeniach, określające uprawnienia do wykonywania zawodu nauczyciela, które nie różnicują pedagogicznego przygotowania I i II stopnia w tym zakresie. Generują więc chaos, są nieprzejrzyste zarówno dla studiujących, przyszłych nauczycieli, jak i dla organizatorów procesów kształcenia. Dzisiaj na polskim rynku edukacyjnym możliwe są takie sytuacje, w których absolwenci studiów magisterskich na kierunku ,pedagogika” nie posiadają tzw. „Uprawnień pedagogicznych” (w myśl obowiązujących rozporządzeń).

- Rekonstrukcja stanu faktycznego w zakresie kształcenia nauczycieli w Polsce oraz towarzysząca jej ocena. 
- Konieczność uczynienia studiów I stopnia (licencjackich) studiami zawodowymi, zapisana w Ustawie z dnia 27 lipca 2005 r. Prawo o szkolnictwie wyższym implikuje potrzebę przedefiniowania studiów uniwersyteckich. Kształcenie nauczycieli na akademickich studiach przedmiotowych pozwoli uniwersytetom odpowiedzieć na pytanie, czym dziś są studia zawodowe.

- Analiza koncepcji organizacji procesu kształcenia nauczycieli w krajach Unii Europejskiej - ma ono charakter równoległy (specjalistyczno-pedagogiczny) i jest równoważne w obu tych wymiarach.

- Podstawowe postulaty wynikające z ustaleń współczesnej pedeutologii oraz badań nad przygotowaniem zawodowym nauczycieli w Polsce i na świecie.

\section{Cechy proponowanego systemu kształcenia nauczycieli}

Integralność - spostrzeganie kompetencji nauczycielskich jako całości złożonej z:

- Wiedzy kierunkowej (specjalistycznej, niepedagogicznej).

- Wiedzy psychologiczno-pedagogicznej.

- Umiejętności wykraczających poza wąsko rozumianą rolę nauczyciela rozumianego jako specjalisty od przekazywania wiedzy; przekraczające tę rolę umiejętności, odpowiadające szeroko pojętej profilaktyce, diagnozie i terapii pedagogicznej.

- Równowaga - kształcenie nauczycieli w równym stopniu uwzględnia przygotowanie kierunkowe (specjalistyczne, niepedagogiczne) i pedagogiczne.

- Elastyczność - zdobywanie pełnego przygotowania zawodowego może odbywać się w ramach różnie skomponowanych programów kształcenia, ważne aby każdy $\mathrm{z}$ tych wariantów zapewniał integralność i równowagę treści kierunkowych (specjalizacyjnych, niepedagogicznych) i pedagogicznych.

Autorska koncepcja kształcenia nauczycieli została opracowana, uszczegółowiona (treści, cele, efekty kształcenia zróżnicowane odpowiednio do stopnia i poziomu kształcenia, na jakim pracuje nauczyciel) i zaakceptowana zarówno przez środowisko pedagogów (pracowały nad nią wszystkie ośrodki akademickie $\mathrm{z}$ całej Polski, zaangażowali się $\mathrm{w}$ tę pracę między innymi tacy Badacze jak prof. Maja Chomczyńska- Rubacha, prof. Beata Przyborowska, prof. Stefan Kwiatkowski), jak i przez Radę Główną Szkolnictwa Wyższego, do której zadań należało przygotowanie i przed- 
stawienie Ministrowi Nauki i Szkolnictwa Wyższego standardu kształcenia nauczycieli.

Spór, jaki wówczas się rozpoczął, jego genezę, przebieg i konsekwencje próbowałam zinterpretować przy użyciu Krytycznej Analizy Dyskursu (KAD).

\section{Władza nad dyskursem}

Przyjęcie perspektywy dyskursywnej pozwala na postawienie pytania o władzę, która nad opisywanym działaniem jest sprawowana, o ośrodki tej władzy, stosowane praktyki, posiadane narzędzia. Pozwala także na postawienie pytania o interesy tej władzy, o cele, jakim jest podporządkowana, o rezultaty, których się spodziewa. i wreszcie: przyjęcie tej perspektywy odsłania język władzy, dążący do hegemonii, do panowania nie tylko nad rodzajem praktyki społecznej, której dotyczy, i którą opisuje, ale także do sposobu uzasadnień, jakimi się posługuje, do sfery symbolicznej, którą współtworzy i legitymizuje.

Analiza pisemnych wypowiedzi, skierowanych do Przewodniczącego Rady Głównej Szkolnictwa Wyższego przez Rektorów Uczelni, które dotąd kształciły nauczycieli pokazała, iż władzę nad dyskursem tego kształcenia sprawuje liczna, marginalizowana w macierzystych środowiskach grupa dydaktyków przedmiotowych. To w imieniu tej grupy (dużo liczniejszej w każdej z uczelni niż grupa pedagogów, zainteresowanych zmianą obecnego, karykaturalnego sposobu kształcenia nauczycieli) Rektorzy twierdzili, że:

- Proponowana zmiana jest archaiczna, zupełnie nieadekwatna do potrzeb współczesnej szkoły.

- Proponowana zmiana jest zbyt nowoczesna, wręcz nowatorska i nie może być, ze względu na innowacyjność opisanych w niej rozwiązań wprowadzona do polskich Uczelni.

- Wiedza psychologiczna i pedagogiczna nie jest potrzebna współczesnemu nauczycielowi.

- Wiedza psychologiczna i pedagogiczna przeszkadza, „szkodzi” kandydatom na nauczycieli.

- Uzupełnienie standardu kształcenia nauczycieli o wiedzę psychologiczno - pedagogiczną automatycznie obniży poziom i jakość ich przygotowania przedmiotowego, z zakresu np. matematyki, fizyki, chemii, historii.

- Treści i kompetencje psychologiczne i pedagogiczne nie są zupełnie potrzebne nauczycielowi, gdyż funkcją współczesnej szkoły jest przekaz wiedzy, trzeba więc przygotowanie do wypełnienia tej funkcji oprzeć 
na wiedzy metodycznej, odpowiadającej na pytanie o to, jak skutecznie, efektywnie, bez zbędnych strat i napięć ,przetransmitować” czy też „przetransferować” posiadane przez nauczyciela informacje z zakresu nauczanego przedmiotu do umysłu ucznia.

Tak więc ośrodkami sprawującymi władzę nad kształceniem nauczycieli w Polsce są szkoły wyższe każdego typu (rolnicze, ekonomiczne, gospodarstwa wiejskiego, artystyczne, uniwersytety i szkoły zawodowe), które dotąd kształcą u siebie nauczycieli, często, jak to powiedział jeden z Rektorów, dzięki obecności jednego, od dawna zatrudnionego adiunkta z pedagogiki i pokaźnej grupie metodyków szczegółowych. Narzędziem sprawowania władzy nad dyskursem kształcenia nauczycieli stają się akty normatywne tworzone przez urzędników dwóch zaangażowanych $\mathrm{w}$ tę działalność ministerstw: MEN-u i MNiSzW. Stosowane praktyki władzy to nakaz wypełniania obowiązków wynikających z obowiązujących rozporządzeń. Żadne sugestie przedstawicieli środowiska akademickiego pedagogów, dysponujących diagnozami opartymi na wieloletnich badaniach szkoły, pracujących w niej nauczycieli, efektów pracy tej instytucji, jej problemów, i stojących przed nią zagrożeń, nie są nawet przesłanką dla obowiązujących i wpisanych w akty normatywne postanowień. Władza nad dyskursem kształcenia nauczycieli w Polsce opiera się więc na praktyce wykluczenia przedstawicieli dyscypliny akademickiej, jaką jest pedagogika, z pracy nad koncepcją i sposobem kształcenia nauczycieli. Sprawują ją uczelnie zainteresowane budżetowym finansowaniem tego kształcenia, co w sytuacji nadciągającego niżu demograficznego może stać się podstawą pozyskiwania środków umożliwiających ich funkcjonowanie. Narzędziami tej władzy są akty normatywne, w których stanowieniu biorą czynny udział przedstawiciele (cytowani Rektorzy) Państwowych Szkół Wyższych kształcących nauczycieli.

\section{Dyskurs władzy w kształceniu nauczycieli}

W świetle Krytycznej Analizy Dyskursu widać wyraźnie, iż dyskurs władzy w kształceniu nauczycieli w Polsce oparty jest na interesie finansowym, na gwarantowaniu sobie dostępu do środków budżetowych na tok? kształcenia oraz blokowaniu dostępu do tych środków innym podmiotom. Brak kryteriów merytorycznych, określających kto może kształcić nauczycieli, niechęć do ich stanowienia, a nawet do rzeczowej rozmowy na ich temat, to kolejne cechy tego dyskursu, które demaskują jego interes finansowy. Szkoła, nauczyciel, uczenie się i kształcenie są w tym dyskursie traktowane przedkrytycznie. Dominuje potoczne i archaiczne myślenie o szkole jako miejscu przyswajania wiedzy 
pewnej, opartej na oświeceniowym modelu nauki, wiedzy, której przyswojenie gwarantuje uczniowi przystosowanie się do rzeczywistości, sprawne w niej funkcjonowanie, jest obietnicą sukcesu. Nie ma w tym dyskursie miejsca na refleksję dotyczącą miejsca i funkcji szkoły we współczesnym społeczeństwie, tak odmiennym od tego, dla którego potrzeb instytucję tę powołano do życia. Nie ma też w nim mowy o takich funkcjach szkoły jak profilaktyka, diagnoza i terapia - funkcjach, które właśnie ze względu na opisywane w naukach społecznych powszechnie problemy naszego społecznego życia wydają się dzisiaj nam pedagogom pierwszoplanowe. Ta zupełna nieobecność w naszym kraju krytycznej refleksji pedagogicznej we współczesnym dyskursie kształcenia nauczycieli została nazwana podczas jednego z seminariów naukowych w Dolnośląskiej Szkole Wyższej przez Roberta Kwaśnicę „upokorzeniem pedagogiki”. O szkole, nauczycielu, uczniu, uczeniu się, dyskutuje i decyduje się w naszym kraju bez udziału specjalistów - przedstawicieli dyscypliny akademickiej. Rolę ekspertów pełnią tutaj metodycy, praktycy, decydenci oświatowi (czyli politycy). Jest to sytuacja zupełnie wyjątkowa, niewyobrażalna na przykład w obszarze praktyk medycznych - wyobraźmy sobie, iż o kształceniu przyszłych lekarzy nie współdecydują przedstawiciele nauk medycznych, że sami lekarze, dyrektorzy placówek medycznych i politycy debatują i decydują o treściach, formie i przebiegu tego kształcenia. Tak jak istnieje wiedza medyczna, rozwijana w ośrodkach akademickich (w akademiach i uniwersytetach medycznych), istnieje także wiedza pedagogiczna, rozwijana na uniwersytetach i innych uczelniach wyższych, w których funkcjonują wydziały pedagogiczne. W naszym kraju rozwija się dynamicznie subdyscyplina, która dotyczy zawodu nauczyciela - jest nią pedeutologia. Prowadzone na jej obszarze badania, tworzone koncepcje i proponowane ich aplikacje dotyczą wprost tego, jakich kompetencji i jakiej wiedzy potrzebuje dzisiaj nauczyciel, jakie może pełnić dziś funkcje w szkole, która nie jest już jedynym miejscem zdobywania wiedzy, lecz staje się jednym z niewielu miejsc regularnych kontaktów społecznych młodych ludzi, funkcjonujących na co dzień „w sieci”. Zamienienie dyskursu naukowego, pedagogicznego na dyskurs potoczny, z jednej strony otwiera go na niekompetentnych dyskutantów, na wiedzę potoczną, opartą o własne, szkolne doświadczenia pochodzące z przeszłości, z drugiej zaś zamyka możliwość uczynienia go profesjonalnym. Władza potoczności, myślenia zdroworozsądkowego w dyskursie kształcenia nauczycieli jest także elementem degradacji tego zawodu, umieszcza go w sferze praktyk dostępnych dla wszystkich, praktyk nie wiążących się z jakimiś szczególnymi kompetencjami i oczekiwaniami. Wyraźna jest tutaj rozbieżność między sferą deklaratywną a rzeczywistą. 
W sferze deklaratywnej o nauczycielu mówi się i pisze w sposób życzeniowy, normatywny, wręcz idealizacyjny. Mówi się o misji, o szczególnych predyspozycjach i umiejętnościach niezbędnych do jego wykonywania. W sferze realnej praktyki proponuje się przygotowanie do tego zawodu traktowane jako „uzupełnienie” wykształcenia przedmiotowego, marginalnie traktowane, i tak też w szkołach wyższych organizowane. Narzędziem dzięki któremu powyższe praktyki dyskursywne są możliwe jest język. Jest on kwiecisty pełen przymiotników, zabarwiony emocjami i nierealnymi oczekiwaniami wtedy, kiedy dotyczy deklaracji związanych z zawodem nauczyciela, natomiast oszczędny, ascetyczny i instrumentalny wtedy, kiedy w rozporządzeniach MEN-u określa on wymagania, jakie muszą spełnić kształcący się nauczyciele. Jest ideologiczny w sferze oczekiwań i zredukowany pragmatycznie w sferze realizacji. Paradoksalnie wzrost poziomu ideologizacji tego języka pociąga za sobą zwiększenie się poziomu redukcji pragmatycznej w sferze proponowanego modelu kształcenia. Oto przykład: każda refleksja krytyczna (jak np. artykuł B. Igielskiej, „Nauczyciele. Non Fiction”, Polityka nr 15/2010) zwiększa poziom normatywizmu opisu nauczycielskiej roli. Mówi się o sprawiedliwym, innowacyjnym, kompetentnym, nowoczesnym, profesjonalnym, empatycznym, otwartym rozumiejącym Mistrzu. Z drugiej zaś strony MEN proponuje obniżenie poziomu wymagań związanych z wykształceniem dla nauczycieli edukacji wczesnoszkolnej. Pragmatycznej redukcji w sferze rzeczywistej praktyki towarzyszy więc ideologiczny wzrost patosu w sferze werbalnej, dotyczącej zawodu nauczyciela.

Uczestnikami dyskursu kształcenia nauczycieli w Polsce jest kilka grup. Poza decydentami oświatowymi są to dydaktycy przedmiotowi oraz pedagodzy i psycholodzy. Podczas prac nad koncepcją i standardem kształcenia nauczycieli okazało się, iż rolę osób decydujących o jednym i drugim chcą pełnić dydaktycy przedmiotowi. Ujawnił się więc ważny społecznie problem istnienia w polskich uczelniach dwóch, nie współpracujących ze sobą, często niewiele wiedzących o sobie nawzajem grup zawodowych: pedagogów, badających, opisujących i analizujących problemy szkoły, uczenia się, relacji nauczyciel uczeń, oraz dydaktyków przedmiotowych (chemii, matematyki, biologii), poszukujących odpowiedzi na pytanie: jak skutecznie nauczać własnego przedmiotu? Pedagodzy reprezentują własną dyscyplinę naukową, mogą rozwijać się w jej obrębie naukowo. Dydaktycy przedmiotowi nie mają takich możliwości. Dla przedstawicieli własnej dyscypliny chemik, który zajmuje się dydaktyką chemii nie jest specjalistą, nie rozwija się zawodowo w obszarze dyscypliny. Nie jest on także specjalistą dla pedagoga, nie uczestniczy w wymianie myśl, 
nie jest badaczem w obrębie tej dyscypliny. Mamy więc do czynienia z podwójnym wykluczeniem: $\mathrm{z}$ jednej strony wykluczeni są pedagodzy opisujący szkołę, relacje nauczyciel - uczeń, dysponujący wynikami badań w tym zakresie, którzy nie mają możliwości aplikacji własnych badań oraz są pozbawieni zarówno wpływu na bieg zdarzeń, jak i odpowiedzialności za tych zdarzeń stan. $Z$ drugiej zaśs strony są dydaktycy przedmiotowi, którzy nie mając przygotowania z zakresu psychologii, pedagogiki (w tym z dydaktyki ogólnej) nie biorą udziału w naukowej debacie o szkole, nauczycielu, procesach uczenia się, są $\mathrm{z}$ tej debaty, a także z zawodowego rozwoju w tym obszarze, wykluczeni, jednakże decydują o tych procesach, biorąc udział w kształceniu nauczycieli, biorą także za ten proces odpowiedzialność.

W świetle powyższych rozważań widać więc wyraźnie, iż problem kształcenia nauczycieli analizowany w perspektywie dyskursywnej, przy użyciu Krytycznej Analizy Dyskursu ujawnia bardzo poważne, niedostrzegane lub nieujawnione wcześniej cechy następujące:

- Dominacja instytucjonalna nad dyskursem (Politycy - MEN, MNiSzW, Rektorzy szkół wyższych).

- Przewaga wiedzy potocznej nad profesjonalną w dyskursie.

- „Gra w ekspertów” polegająca na obsadzeniu w tej roli nauczycieli praktyków, polityków, urzędników oświatowych w miejsce badaczy problemów nauczyciela, szkoły, uczenia się, pedagogów skupionych w akademickich ośrodkach badawczych. To swoiste „odwrócenie ról” występuje, jak sądzę jedynie w odniesieniu do tego problemu i tego środowiska. Analiza przyczyn i uwarunkowań tego zjawiska, pozwalająca na udzielenie odpowiedzi na pytanie, dlaczego tak się stało, jak to jest możliwe, to materiał dla kolejnej analizy krytycznej.

- Podporządkowanie dyskursu interesowi finansowemu oraz interesom jednej grupy zawodowej (dydaktyków przedmiotowych).

- Praktyki językowe służące ukryciu prawdziwego interesu, celu dyskursu. Ideologiczność, fasadowość, życzeniowy charakter języka, w jakim formułuje się opisy zawodowej roli nauczyciela mają maskować podporządkowanie dyskursu interesom finansowym i utrzymaniu status quo przez zaangażowane $\mathrm{w}$ kształcenie nauczycieli osoby.

- Banalizacja dotycząca zarówno debaty dotyczącej kształcenia nauczycieli w Polsce jak i jej praktycznej realizacji.

- „Upokorzenie pedagogiki” jako dyscypliny naukowej zajmującej się problematyką nauczyciela i szkoły polegające na dominacji potocznych, ideologicznych i praktycznych uzasadnień proponowanych rozwiązań. 
- Przedkrytyczne, archaiczne traktowanie szkoły, oparte na sprowadzaniu tej instytucji jedynie do przekaźnika wiedzy.

- Opór i lęk przed zmianą mimo krytycznych diagnoz i opisów stanu i funkcjonowania współczesnej, polskiej szkoły i dramatycznych, medialnych doniesień o niekompetencji nauczycieli w zakresie innych niż związane z przekazywaniem wiadomości z zakresu nauczanego przedmiotu umiejętności.

Sądzę, iż wszystkie te cechy pozwalają sformułować tezę, że dyskurs kształcenia nauczycieli w Polsce jest stale jeszcze dyskursem POZORU." (Nowak-Dziemianowicz, 2011, s. 198).

Krytyczny namysł nad edukacją, szkołą i nauczycielem jest jednak tylko jednym z obszarów moich zainteresowań badawczych. Kolejnym z nich, na przykładzie którego spróbuje także przedstawić pokrótce mój autobiograficzny wysiłek badawczy skierowany ku emancypacyjnym badaniom społecznym, jest pytanie o relacje między ludźmi, związki intymne, małżeństwo, rodzinę, o to, co dzieje się w nich „pomiędzy”: małżonkami, partnerami, rodzicami i dziećmi.

\section{Od triangulacji do jakościowych badań nad relacjami, związkami i tożsamością.}

Moja aktywność badawcza w tym obszarze podporządkowana jest pytaniu o to, co w naszych relacjach z innymi sprzyja szczęśliwemu, dobremu życiu, a co w nim przeszkadza, utrudnia, ogranicza, staje się swoistą blokadą rozwojową. Jest to więc pytanie o przestrzenie, w których człowiek buduje swoją tożsamość: dla siebie, dla innych, ze sobą i z innymi. Jest to więc także pytanie o określony kontekst społeczno-kulturowy, w którym podejmujemy zadanie pracy nad własną tożsamością, nad naszą historią; pytanie o ,ja”. Kontekst ten tworzą wartości, normy i wzorce kultury, stanowiące jednocześnie podstawę ładu społecznego, w którym żyjemy i budujemy relacje z innymi. Pytanie o sposoby, za pomocą których współczesny człowiek konstruuje swoją tożsamość musi być zatem pytaniem o jego relacje z innymi, o jego związki intymne, małżeństwo, rodzinę i rodzicielstwo. Musi być także pytaniem o wpisane w te relacje cierpienie, nawet o potencjał tego cierpienia. Małżeństwo i rodzina, związki intymne i rodzicielstwo to nadal, jak pokazują badania, najważniejsze wartości deklarowane przez Polaków. Jakie znaczenia przypisujemy tym ważnym dla nas, konstytuującym naszą tożsamość wartościom? Kiedy i w jakich warunkach możemy je realizować w sposób satysfakcjonujący, prowadzący do szczęścia, do dobrego życia, a kiedy i dlaczego doświadczamy w tych relacjach cierpie- 
nia? Czy możemy go uniknąć, jak się przed nim bronić i wreszcie - jak sobie radzić z tym cierpieniem - to pytania, które składają się na drugi obszar moich zainteresowań naukowych. W tym obszarze mieści się oparta na rozprawie doktorskiej praca „Małżeństwo wobec rozwodu” (Nowak-Dziemianowicz, 1994). W tej książce stosuję triangulację, łączę badania korelacyjne, szukające związku między zoperacjonalizowanymi zmiennymi (takimi jak: poczucie wpływu na bieg zdarzeń, wewnętrzna kontrola wzmocnień, zapotrzebowanie na aprobatę społeczną, poziom lęku, orientacja temporalna, orientacja na innych ludzi, życie towarzyskie, aktywność społeczną, poczucie własnej wartości) a powodzeniem lub porażką w małżeństwie, $\mathrm{z}$ wywiadem klinicznym, przeprowadzonym z parami będącymi w trakcie postępowania rozwodowego. Na tej podstawie próbuję odpowiedzieć na pytanie o przyczyny konfliktów małżeńskich oraz o możliwości przeciwdziałania czy też radzenia sobie z kryzysem małżeńskiego związku. Ta problematyka także jest zakorzeniona w moim własnym doświadczeniu. Jestem reprezentantką pokolenia tzw. „emigracji wewnętrznej”, której jednym z przejawów była „ucieczka do środka”, ucieczka w prywatność. Brak perspektyw, brak możliwości samorealizacji, który stał się udziałem mojego pokolenia w latach 80-tych sprawil, iż wiele młodych ludzi zawierało związki małżeńskie bez głębszego namysłu, wybierając jedyny dostępny wówczas pomysł na własne życie. Takie motywacje do zawarcia małżeńskiego związku ujawniły przeprowadzone $w$ ramach rozprawy doktorskiej badania. Również ja uległam tym powszechnym wzorcom. Rozwód stał się także moim doświadczeniem biograficznym. Żeby zrozumieć tę niezwykle traumatyczną sytuację podjęłam wówczas pracę w Sądzie Rodzinnym we Wrocławiu - najpierw jako kurator społeczny a później jako pedagog-diagnosta w Rodzinnym Ośrodku Diagnostycznym przy Sądzie Wojewódzkim we Wrocławiu. Pełnienie tych ról zawodowych umożliwiło mi prowadzenie badań nad rozpadem związku małżeńskiego. Kontynuuję je do dzisiaj. Opisuję w nich rozwód jako zdarzenie krytyczne, próbuję odejść od funkcjonalno-strukturalnego spojrzenia na rodzinę, podążając w stronę optyki rozumiejącej. Moja książka pod tytułem „Doświadczenia rodzinne w narracjach. Interpretacja sensów i znaczeń" (wydanie pierwsze - 2002, wydanie drugie - 2006), była jedną z pierwszych w polskiej pedagogice prób ulokowania badań nad małżeństwem i rodziną w perspektywie hermeneutyczno-fenomenologicznej. Przeprowadziłam wówczas wywiady narracyjne z ludźmi, którzy swoje małżeństwo uważali za szczęśliwe i udane oraz z tymi, którzy doświadczyli rozwodu. Książka ta składa się z dwóch części. Pierwsza nosi tytuł: „Poszukiwanie stanowiska badawczego”. Tym, co jest w tej części najważniejsze dla mojego późniejszego rozwoju są zre- 
konstruowane przez mnie, obecne w polskiej pedagogice rodziny, socjologii rodziny i psychologii rodziny typy wiedzy o rodzinie. Wskazuję w niej techniczno-instrumentalny dyskurs o rodzinie, normatywny dyskurs o rodzinie oraz praktyczno-moralny dyskurs o rodzinie. Przykładów dwóch pierwszych typów dyskursów dostarczyła mi literatura przedmiotu z trzech wymienionych wyżej dyscyplin, zajmujących się tą problematyką. Trzeci rodzaj dyskursu, trzeci typ wiedzy o rodzinie zaproponowałam jako sposób na przezwyciężenie ograniczeń, uproszczeń i stereotypów dwóch poprzednich dyskursów. Nazwałam go za Robertem Kwaśnicą dyskursem praktyczno-moralnym (dostrzegając oczywiście jego źródła w teorii działania komunikacyjnego Jürgena Habermasa). Dyskurs normatywny wiedzy o rodzinie charakteryzuje się aksjologicznymi założeniami, które są jego punktem wyjścia. Nie zawsze ujawniane traktowane bywają jako norma czy zobowiązanie, którego złamanie grozi sankcją społeczną. W tym ujęciu rodzina musi być pełna i trwała. Każda inna relacja, każda inna sytuacja między ludźmi nazywana jest patologią lub odstępstwem od normy. Dyskurs ten generuje modelową wiedzę na temat pożądanych stylów wychowania, pożądanych form, metod, środków małżeńskiego życia, wychowania dzieci, relacji miedzy małżonkami, między rodzicami i dziećmi. Tworzy więc model całkowicie abstrahujący zarówno od kontekstu społeczno-kulturowego, w którym funkcjonują ludzie, w którym żyją, zawierają związki i wychowują dzieci. Tworzy model nie zwracający uwagi (niezdolny do dostrzeżenia) tego, co naprawdę dzieje się między ludźmi. Dyskurs techniczno-instrumentalny oparty jest na niezwykle w Polsce popularnej (niestety do dzisiaj) strukturalno-funkcjonalnej koncepcji społeczeństwa oraz tworzących je grup (takich, jak w tym ujęciu rodzina). Każda struktura społeczna ma do spełnienia swoją funkcję opisaną, zaprojektowaną i zapewniającą harmonię społeczeństwa jako całości. Badacze społeczni mają za zadanie funkcje te opisywać oraz pokazywać wszelkie przejawy odstępstwa od ich wypełniania.

O trzecim, zaproponowanym przez siebie typie dyskursu pisałam tak:

„Sądzę, iż praktyczno-moralna wiedza o rodzinie opierałaby się na rozumiejącym, refleksyjnym wglądzie w intersubiektywne doświadczenie, jakie towarzyszy człowiekowi w jego życiu rodzinnym. Dotyczyłaby sensów oraz znaczeń, jakie ludzie nadają swemu doświadczeniu, jakie wiąże się z ich życiem rodzinnym. Dopuścilaby do głosu te wszystkie sensy i znaczenia, które pojawiają się jako odpowiedź na pytanie: co to dla mnie znaczy być rodzicem, czym jest wychowanie dziecka, czym jest dla mnie bycie żoną lub mężem, jakie znaczenie ma dla mnie dom rodzinny, kim jest dla mnie drugi człowiek, co w relacji z nim pragnę osiągnąć, jak 
i co określam mianem sukcesu? Co w moim życiu rodzinnym sprawia mi trudność, co stanowi przeszkodę nie do pokonania, co, jakie problemy potrafię rozwiązać, dzięki jakim działaniom, uzasadnieniom i racjom staje się to możliwe? Czym jest kryzys w życiu rodzinnym, przeżyte niepowodzenie, doświadczenie cierpienia? To pytania, które, jak sądzę, wymagają odpowiedzi, dzięki której możliwy stałby się rozumiejący (a nie tylko normatywno-ideologiczny czy też instrumentalno-techniczny) wgląd w jednostkowe, subiektywnie przeżywane i traktowane życie rodzinne.

Taki rozumiejący wgląd mógłby stać się początkiem budowania nowego typu wiedzy o rodzinie - wiedzy, dzięki której badacz, pedagog mógłby odkryć rzeczywiste sensy i znaczenia, jakie doświadczający rodzinnego życia ludzie przypisują różnym przejawom swej codzienności a także dzięki której mógłby rozumieć własne uprzedzenia, kierujące swym działaniem stereotypy, przesądy i ukryte założenia." (Nowak-Dziemianowicz, 2006, s. 49).

W publikacjach z tego obszaru, ulokowanych w orientacji jakościowych badań zaangażowanych poruszam następujące wątki i problemy rodzinnego życia:

- Problem tożsamości oraz znaczenia relacji rodzinnych dla jej konstruowania.

- Problem bezpieczeństwa ontologicznego i podstawowego zaufania, jakie charakteryzują te relacje traktuję (zgodnie ze współczesnymi teoriami tożsamości m.in. Eriksona, Giddensa, Becka, Kaufmanna,) jako warunek i konieczność dla pracy nad własną podmiotowością. Rozwijam przy tym wybraną, rozumiejącą perspektywę metodologiczną, gdyż pytanie o tak osobiste i subiektywne doświadczenie, jak konstruowanie własnego poczucia ,ja”, nie może być ujmowane jako fakt obiektywny i badane w sposób charakterystyczny dla orientacji pozytywistycznej.

- Problem współczesnego rodzicielstwa. W odniesieniu do tego problemu przyjmuję perspektywę hermenutyczno-krytyczną. Tylko dzięki wsłuchaniu się w opowieści dotyczące rodzicielskich doświadczeń innych ludzi otrzymujemy rodzaj rozumiejącego wglądu w ten obszar, możemy zrozumieć i opisać zachodzące $\mathrm{w}$ rodzinie procesy wychowania.

- Problem ucieczki od wychowania. Perspektywa krytyczna zastosowana w odniesieniu do tej problematyki pozwala dostrzec niepokojący społecznie proces odwrotu od wychowania rozumianego jako budowanie więzi, bliskości, czasami poświęcenia się na rzecz własnego dziecka, na rzecz „bankowej” koncepcji dziecka, traktowania go jako inwestycji, 
lokaty na przyszłość czy też chwilowego zakłócenia (niedogodności?) we własnych planach życiowych. Nowe rodzicielstwo bywa często niezdolne do wysiłku, trudu i altruizmu. Stojąc przed wyborem miedzy tym, co ważne dla mnie, a tym, co ważne dla dziecka, współcześni indywidualiści wybierają często orientację na ,ja”, prezentując w ten sposób egoizm oraz obojętność na potrzeby własnych dzieci.

- Problem rodzinnych doświadczeń bywających źródłem cierpienia. Należy do nich nie tylko rozwód jako doświadczenie krytyczne. Źródłem cierpienia mogą być także codzienne praktyki rodzinnego wykluczenia, zrywania więzi, odmowy komunikacji, deficytu bezpieczeństwa, zaufania i wsparcia. Samotni z bliskimi, osamotnieni w rodzinie to częste dzisiaj doświadczenia egzystencjalne współczesnych młodych i dorosłych. Opisuję je przede wszystkim w tekście: Kiedy miejsca już nie ma: rodzinne praktyki wykluczenia (Nowak-Dziemianowicz, 2006a).

- Problem rodzinnej socjalizacji do ról związanych z płcią. Rozwijam to zagadnienie zarówno w tekstach, jak i podczas konferencji naukowych. Próbuję pokazać, iż kulturowe wzorce określające w sposób domknięty rolę społeczną kobiety pełnią funkcję blokady rozwojowej w realizacji ważnych dla niej biograficznie zadań, znajdujących się poza modelem tej roli. Pokazuję nierówność wpisaną w tę socjalizację rodzinną, obecną nawet w współczesnych tekstach polskich psychoterapeutów (np. W. Eichelberga).

\section{Podsumowanie. Specyfika jakościowych badań zaangażowanych}

Zaprezentowane wyżej wybrane fragmenty autobiografii zawodowej mogą stać się przykładem odmienności między dwiema obecnymi dzisiaj w humanistyce i naukach społecznych orientacjami. Różnicom tym poświęciłam wiele artykułów (Nowak-Dziemianowicz, 2002, 2011, 2012, 2016). Dzisiaj, z perspektywy dyskusji i sporów, jakie toczą się wokół tych zagadnień, wydaje mi się, iż najważniejsze z nich to:

1. Sposób postrzegania i traktowania świata społecznego. W orientacji pozytywistycznej na świat ten składa się zbiór materialnych i niematerialnych faktów (obiektów, zdarzeń, sytuacji). Ich status jest porównywalny, można je więc identycznie traktować, badać i wyjaśniać. W orientacji interpretatywnej świata wychodzimy od tezy, iż świat społeczny różni się zasadniczo od świata materialnego, świata przyrody. Świat społeczny ma językowy charakter. Istnieje w języku i poprzez 
język. Język zaś jest konstruowany społecznie, dynamiczny, ciągle zmieniany, zakorzeniony $\mathrm{w}$ trzech porządkach czasu - w przeszłości, teraźniejszości i przyszłości, a także niejednoznaczny, gdyż niesie za sobą zarówno sens jak i znaczenie. Badać świat społeczny to badać jego przejawy językowe (aktualizujące się w języku i poprzez język, ale także za pomoca języka opisywane). Ograniczeniem takich badań są więc granice języka - to, co niewyrażalne, czego nie da się, czego nie można wysłowić. Ograniczenia te dotyczą w takim samym stopniu badanego świata (ludzi, ich przeżyć, ich doświadczeń, ich świata), jak i samego badacza - granice jego językowych kompetencji stanowią granice poznania.

2. Status badanego świata. W badaniach ulokowanych w orientacji pozytywistycznej dążymy do obiektywizacji zarówno ich przedmiotu jak i stosowanych procedur oraz uzyskanych wyników. Obiektywizm - najszerzej rozumiany - ma nam umożliwić zarówno generalizację uzyskanych wyników, jak i proces ich uogólniania. W interpretatywnej orientacji badań subiektywizm staje się ich cechą i wartością, uświadomioną koniecznością. Interpretatywnym badaczom towarzyszy przekonanie, iż tylko subiektywny wgląd w eksplorowany obszar rzeczywistości jest wglądem możliwym, iż wszelka obiektywizacja staje się w odniesieniu do społecznego świata iluzją czy nawet przekłamaniem.

3. Relacja badacz-przedmiot badań. Podobnie ma się sprawa ze stosunkiem badacza do badanej rzeczywistości. W orientacji pozytywistycznej jest to relacja nadrzędności - badacz „pochyla” się nad badaną rzeczywistością, jest od niej oddzielony powagą swoich procedur i metod. To one dają badaczowi poczucie górowania nad tym, co w tej orientacji nazywa się (nie bez powodu) przedmiotem badań. Wyposażony w coraz to doskonalsze, obiektywne metody, badacz panuje poznawczo nad światem, eksploruje go intelektualnie, wykorzystuje, zawłaszcza. W interpretatywnej orientacji badań relacja między badaczem a interesującym go fragmentem rzeczywistości wygląda natomiast inaczej. Badacz jest zawsze częścią badanej rzeczywistości społecznej, uczestnikiem badanych zdarzeń, staje się podmiotem doświadczającym (lub mogącym doświadczyć) każdej z badanych przez siebie sytuacji. Badacz interpretatywny ma tego świadomość. Zdaje sobie on sprawę $z$ tego, że językowy charakter badanych zdarzeń (w tym także zdarzeń dyskursywnych) sprawia, iż będąc tym, który je poznaje, jest zawsze jed- 
nocześnie tym, który je tworzy. Stanowiąc część wspólnoty, badacz jak każdy z jej członków - uczestniczy w procesie nadawania znaczeń, w procesie ich negocjowania. Badam zdarzenia krytyczne jako coś, co moja wspólnota określa mianem takich zdarzeń, badam je także jako ktoś, kto ich jednocześnie doświadcza i uczestniczy w ich nazywaniu, określaniu ich przejawów, ich ważności i roli, jaką mogą pełnić (i pełnią) one w naszym życiu. Każdy badacz społeczny może być więc traktowany jako część badanej przez siebie rzeczywistości. Nawet wtedy, kiedy bezpośrednio nie dotyczą go badane sytuacje, dzięki wyobraźni narracyjnej ma on świadomość, że kiedyś, w innych warunkach, w wyniku nieprzewidzianych zdarzeń mogą stać się także częścią jego doświadczenia. Dlatego relację między badaczem a badaną rzeczywistością w orientacji interpretatywnej można nazwać relacją dwupodmiotową, współzależną, współistniejącą. Ja i badany przeze mnie świat społeczny to jedność, to językowa przestrzeń sensów i znaczeń, w której tworzeniu cały czas, przez całe moje życie uczestniczę. Niczym nie różnię się w tym przypadku od innych uczestników życia społecznego. Tak samo jak oni podczas swojej egzystencji, budując historię o swoim ,ja”, uczestniczę w procesie negocjowania znaczeń, jakie różnym jego przejawom nadaje moja wspólnota. Współdecyduję o tym, co badam, jestem tego częścią, współtwórcą, współautorką. Doświadczenia, zdarzenia i sytuacje, które badam są zawsze w jakiś sposób ze mną związane - znam je z codziennego życia jako moje własne lub te, które dotyczą innych członków mojej wspólnoty.

4. Miejsce i rola teorii w badaniach. „W pozytywistycznym paradygmacie badań teoria przesądza o wszystkim. O sposobie, w jaki sformułowane jest pytanie badawcze, o stawianych hipotezach, które są próbą udzielenia na pytanie to odpowiedzi, o sposobie postępowania badawczego. Operacjonalizacja podstawowej kategorii badawczej zamieniona na język wskaźników określa to, jakimi pojęciami, z jakich koncepcji pochodzącymi będziemy się w naszych badaniach posługiwać. Wybrana, adekwatna do języka teorii metoda badawcza pozwoli na zadawanie pytań wyłącznie w obszarze tego właśnie języka. Język wybranej teorii jest więc uprzedni wobec samego badania, jest uprzedni wobec pytania badawczego. Może ono być poprawnie lub niepoprawnie sformułowane. Poprawne jest wtedy, kiedy mieści się w języku wybranej teorii. Niepoprawne jest wtedy, kiedy w najmniejszym nawet stopniu poza język ten wykracza." (Nowak-Dziemianowicz, 2016). Przykładem takiej 
właśnie funkcji teorii mogą być zaprezentowane na początku niniejszego tekstu badania nad autonomią osobowości nauczyciela.

„Zupełnie inaczej sytuacja badawcza oraz sytuacja badacza wygląda w perspektywie interpretatywnej. Tutaj mamy do czynienia $\mathrm{z}$ bezwzględnym prymatem pytania badawczego. To ono jest impulsem dla całego badawczego trudu, to ono uruchamia cały skomplikowany proces badawczy. Pytam o jakiś ważny dla mnie fragment rzeczywistości społecznej, pytam o jakiś ważny dla siebie przejaw ludzkiego życia. To pytanie każe mi wybrać drogę, najlepszą drogę, gwarantującą mi możliwość udzielenia na nie odpowiedzi. Znając pytanie, odnajdując drogę do poszukiwania na nie odpowiedzi, szukam takich teorii, pojęć i kategorii, które mieszczą się w obrębie mojej (i pokrewnych) dyscypliny. Dlatego teoria pojawia się w tych badaniach już po sformułowaniu pytania badawczego, po znalezieniu najlepszego, dostępnego badaczowi sposobu poszukiwania odpowiedzi na to pytanie. Teoria pojawia się $\mathrm{w}$ tych badaniach na wiele różnych sposobów. Nie tak, jak w badaniach pozytywistycznych, gdzie króluje w rozdziale pierwszym i w zakończeniu, w którym językiem tej teorii sformułowane są wnioski. W badaniach prowadzonych $w$ interpretatywnej orientacji metodologicznej teoria (czy też wiele, różnych teorii) pojawia się na każdym etapie, w każdej fazie badań. Najpierw pytanie badawcze, które może mieć dla nas nawet formę potocznego, opartego na jakimś ważnym dla nas doświadczeniu zdania, prowadzi nas w obszar związany z określoną koncepcją teoretyczną. W moim przypadku jest to wywiedziona z filozofii Hegla, rozwijana przez Honnetha kategoria uznania. Następnie, w obrębie tej teorii musi zostać sprecyzowane i postawione pytanie badawcze. Kolejnym krokiem jest wybór orientacji metodologicznej, uzasadnienie jej adekwatności do pytania badawczego, pokazanie ontologicznych i epistemologicznych uzasadnień dla przyjęcia takiej właśnie orientacji badawczej. Krok kolejny to syntetyczny opis różnych, pochodzących z wielu koncepcji i teorii nauk społecznych i filozofii kategorii pojęciowych, które są nam niezbędne do udzielenia odpowiedzi na postawione pytanie badawcze. Ten wysiłek oparty być musi o studia interdyscyplinarne, wielowątkowe, włączające w perspektywę naszych badań także dyskusje i spory. I najważniejsza, najbardziej rozległa i pracochłonna dla tej orientacji badawczej faza to oparta na jakościowych badaniach próba udzielenia odpowiedzi na postawione pytania badawcze. I w tej właśnie fazie teorie, które znamy, i których jeszcze nie znamy, są nam potrzebne, mają dla naszej aktywności badawczej zasadnicze znaczenie. To właśnie językiem tych teorii dokonujemy dwóch ważnych czynności badawczych: prezentujemy narracje, biografie czy autobiografie, będące przedmiotem naszych badań, źródłem naszej wiedzy o badanym zjawisku. 
To językiem tych teorii opisujemy narracje, biografie, autobiografie - dokonujemy ich deskrypcji. To, w jakim porządku je pokażemy, czemu za każdym razem ów pokaz ma służyć jest konsekwencją określonej, przyjętej przez nas i przywołanej w danym fragmencie pracy teorii. To jedna z jej funkcji. Jej funkcja deskryptywna. Druga funkcja teorii w pracach mieszczących się w omawianej orientacji metodologicznej wiąże się z zadaniem dla orientacji tej podstawowym - to funkcja narzędzia interpretacji. Teorie, koncepcje, pojęcia i kategorie wchodzące w ich skład stają się narzędziami, których używamy, próbując odpowiedzieć na stawiane pytania badawcze. Interpretujemy wysłuchane narracje, biografie czy autobiografie poprzez i dzięki tym teoriom, koncepcjom i kategoriom. Robimy to ich językiem, robimy to w ich języku. Języków tych może być wiele - wszakże narracyjne historie o ,ja" nie mieszczą się w jakimś jednym porządku znaczeniowym, nie mogą zmieścić się więc w języku jakiejś jednej teorii. Interpretując czyjeś życie przekraczamy granice dyscyplin, języków, wykraczamy często poza stawiane wcześniej pytania. Robimy to wszystko po to, żeby jak najmniej redukować to, co stanowi oś naszych zainteresowań. Nie redukujemy zaskakujących nawet wyników, emocji, wypowiedzi ani dla czystości metodologicznej ani dla czystości czy elegancji formy naszej badawczej pracy. Dlatego w pracach interpretatywnych teoria (teorie) są wszędzie - nie można wydzielić czy też oddzielić części teoretycznej od reszty pracy. Tak jak metodologia jest wszędzie - na każdej stronie naszej badawczej pracy pokazujemy, czy rozumiemy wybraną przez siebie orientację metodologiczną, czy posługujemy się nią adekwatnie do stawianych w pracy pytań, czy nasz czytelnik wie i rozumie, co i dlaczego w procesie badawczym robimy." (Nowak-Dziemianowicz, 2016).

Mamy dzisiaj dostęp do wielu różnych orientacji metodologicznych. Są one zawsze określone, dokładnie opisane i uzasadnione. Podporządkowane zostają różnym funkcjom nauki, różnym sposobom jej rozumienia, stanowienia jej celów. Mamy więc wybór, mamy możliwość decydowania o tym, co i dlaczego robimy. W prezentowanym artykule pokazałam własną drogę zawodową, własną biografię naukową. Droga ta prowadzi od pierwszych zakorzenionych w pozytywistycznym paradygmacie badań do tych bardzo subiektywnych, angażujących i dotyczących mnie osobiście prób rozumienia i interpretacji takich fragmentów otaczającej mnie rzeczywistości społecznej, w której sama funkcjonuję, która mnie dotyczy, porusza, inspiruje. Pokazałam drogę pełną wątpliwości lecz zawsze bardzo autentyczną, opartą na mocnym przekonaniu, iż tym, co odróżnia humanistykę i nauki społeczne od innych dziedzin jest zawsze bezpośrednie zaangażowanie badacza/badaczki. To zaangażowanie, ta pasja, 
potrzeba a nawet misja zrozumienia otaczającego nas świata oraz jego zmiany na lepsze stają się możliwe dzięki równoprawnej obecności metodologii badań jakościowych we współczesnej epistemologii.

\section{Bibliografia}

Bee H. (2006). Psychologia rozwoju człowieka. Poznań: Zysk i S-ka Wydawnictwo.

Jarymowicz M. (2008). Psychologiczne podstawy podmiotowości. Warszawa: Wydawnictwo Naukowe PWN.

Kwiatkowska H. (2007). Tożsamość nauczycieli. Między anomia a autonomią. Gdańsk: Gdańskie Wydawnictwo Psychologiczne.

Nowak-Dziemianowicz M. (2001). Oblicza nauczyciela, oblicza szkoły. Toruń: Adam Marszałek.

Nowak-Dziemianowicz M. (2002). Doświadczenia rodzinne w narracjach: interpretacje sensów i znaczeń. Wrocław: Wydawnictwo Uniwersytetu Wrocławskiego.

Nowak-Dziemianowicz M. (2006). Doświadczenia rodzinne $w$ narracjach: interpretacje sensów i znaczeń. Wrocław : Wydawnictwo Naukowe Dolnośląskiej Szkoły Wyższej.

Nowak-Dziemianowicz M. (2006a). Kiedy miejsca już nie ma: rodzinne praktyki wykluczenia. W: Mendel M. (red.), Pedagogika miejsca. Wrocław: Wydawnictwo Naukowe Dolnośląskiej Szkoły Wyższej.

Nowak-Dziemianowicz M. (2011). Pedagogika dyskursywna - nadzieje i możliwości. W: Nowak-Dziemianowicz M., Rudnicki P. (red.). Pedagogika: zakorzenienie i transgresja. Wrocław: Wydawnictwo Naukowe DSW.

Nowak-Dziemianowicz M. (2012). Edukacja i wychowanie w dyskursie nauki i codzienności. Kraków: Oficyna Wydawnicza „Impuls”.

Nowak-Dziemianowicz M. (2013). W poszukiwaniu nowej pedagogiki, nowej edukacji, nowej szkoły - reminiscencje. W: H. Červinkova, B. D. Gołębniak (red.). Edukacyjne badania $w$ działaniu. Warszawa: Wydawnictwo Naukowe Scholar.

Nowak-Dziemianowicz M. (2014). Oblicza edukacji: między pozorami a refleksyjna zmianą. Wrocław: Dolnośląska Szkoła Wyższa, 2014.

Nowak-Dziemianowicz M. (2016). Walka o uznanie w narracjach. Jednostka i wspólnota w procesie poszukiwania tożsamości. Wrocław: Dolnośląska Szkoła Wyższa.

Reykowski J., Owczynnikowa O. W., Obuchowski K. (red.) (1985). Studia z psychologii emocji, motywacji i osobowości. Wrocław: ZN im. Ossolińskich. 